\title{
Raw material sources of knapped stone tools from the excavation of the Early Bronze Age site at Toumba Thessaloniki, Greece
}

\author{
Stamatia Karageorgiou ${ }^{1}$, Aikaterini Kostaki ${ }^{2}$, Michail Vavelidis ${ }^{1}$, \\ Stelios Andreou ${ }^{3}$ \\ 1. Aristotle University of Thessaloniki, School of Geology, Department of Mineralogy-Petrology-Economic \\ Geology, 54124, Thessaloniki, Greece. Email: Karageorgiou: matina_mk@hotmail.com; \\ Vavelidis: vavelidi@geo.auth.gr \\ 2. Department of Art History and Archaeology, Université Paris 1 Pantheon, Sorbonne, France. \\ Email: aikaterini.kostaki@gmail.com \\ 3. Aristotle University of Thessaloniki, Faculty of Philosophy School of History and Archaeology, 54124 \\ Thessaloniki, Greece. Email: andrest@hist.auth.gr
}

\begin{abstract}
:
This study investigates the origin of the lithic findings from the prehistoric site at Toumba, Thessaloniki in Greece, during the Early Bronze Age (EBA). The artefacts from the excavation were studied in order to compare the raw materials utilized for the manufacture of these tools with the geological occurrences of the corresponding materials in the broader region. This research provides evidence for the provenance of these materials and consequently some insight into the socioeconomic system of the settlement. For this reason, samples of siliceous sediments were chosen from regions with similar geological formations, such as Vasilika and Galatista. Apart from macroscopic examination, both archaeological and petrographic, microscopic examination was also applied in order to identify the microstructure and the mineralogical context, and finally geochemical study by ICP-MS analysis and XRF spectrometry for determining the major, trace and rare earth element concentrations. The comparison of these features with the archaeological features reveals that during the Early Bronze Age there was possibly a relation between Toumba inhabitants and the regions of Vasilika and Galatista for the procurement of chert. The petrographic examination of the lithic findings shows whether the tools are manufactured in the settlement or if there is an import of tools from other sites.
\end{abstract}

Keywords: lithic sources; chert; geochemistry; reduction sequence; Toumba; Northern Greece

\section{Introduction}

The research focuses on the study of the artefacts and the raw materials that had been used by inhabitants in the prehistoric settlement of Toumba, in Thessaloniki, northern Greece. Specifically, 940 lithic products were examined, including knapped stone tools and debris.

Published by the School of History, Classics and Archaeology, University of Edinburgh ISSN: 2055-0472. URL: http://journals.ed.ac.uk/lithicstudies/

This work is licensed under a Creative Commons Attribution 2.5 UK: Scotland License. 
Moreover, there was a sample selection after fieldwork from the sites of Vasilika and Galatista. These locations seem to be the most prominent chert procurement sites in the region.

Chert, a high-silica rock dominantly composed of $\mathrm{SiO}_{2}$ minerals, and other related siliceous rocks were among the first raw materials utilized in prehistory for the manufacture of knapped tools. The term 'chert' is generally used for fine-grained siliceous sediments which are mainly composed of silica and may contain some impurities as well (Tucker 2001). Sometimes, the term 'flint' refers to nodular cherts that occur in Cretaceous chalks, but flint also indicates all these raw materials used for the construction of tools and weapons by prehistoric man (Mitropoulos et al. 1990). Generally, chert is microcrystalline or cryptocrystalline quartz of inorganic, volcanic, hydrothermal, biochemical or biogenic origin with characteristic hardness and conchoidal fracture (Tucker 2001). In this study, cherts are the main raw materials examined in terms of archaeometry, mineralogy and geochemistry.

\subsection{The prehistoric settlement}

The settlement of Toumba in Thessaloniki is one of the most significant archaeological sites of the Bronze Age in northern Greece. This site, located at the eastern part of the city, has the form of an artificial hill due to residues of human activity (Figure 1) accumulated over at least 2000 years. The settlement rises up to $23 \mathrm{~m}$ above the current land surface and its perimeter reaches $400 \mathrm{~m}$ with a maximum length up to $150 \mathrm{~m}$ and width up to $100 \mathrm{~m}$ (Tsiolaki 2009; Tsoraki 2002).

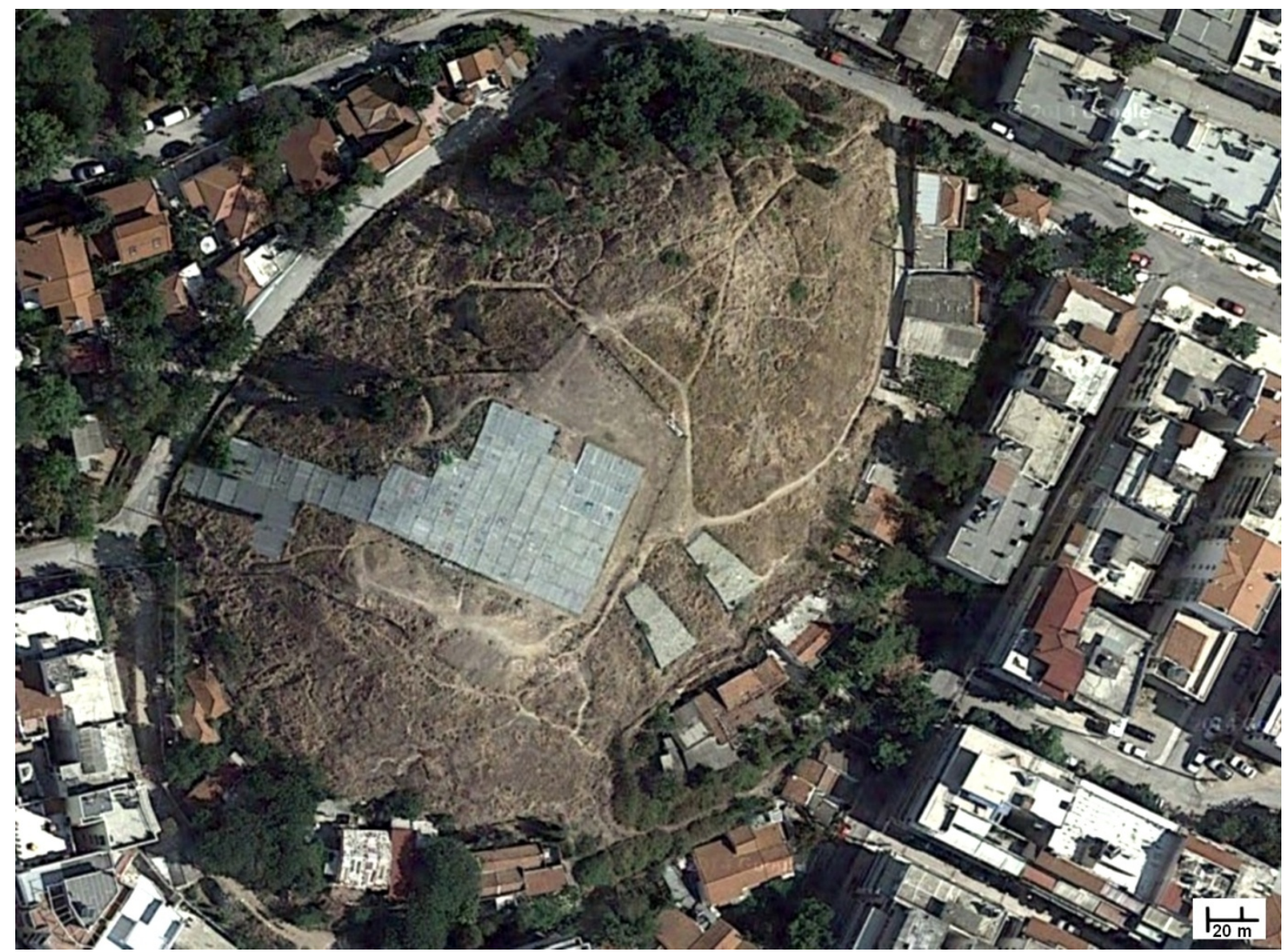

Figure 1. The prehistoric settlement at Toumba, Thessaloniki, northern Greece. This site is located at the eastern part of the city and has the form of an artificial hill. 
Thirteen phases were recognized and the excavations showed that there was continuous habitation starting from the late third or early second millennium B.C.E. (Early Bronze Age) until the late $4^{\text {th }}$ or early $3^{\text {rd }}$ century B.C.E. (Andreou \& Kotsakis 1996). Although habitation appears to be continuous, it is suggested that there were possibly few short time periods of abandonment (Kotsakis \& Andreou 1988). The building phases were identified during excavation, which has been developed in two sections. The first section is the one at the top of the mound and the second one is at the hillside (Tsiolaki 2009). The dating of the various phases is mainly based on the ceramic typology, which is compared to the pottery found at sites in southern Greece (Andreou \& Kotsakis, 1996). The earliest human activity in this site is represented by the building phase XIV (EBA) and by the respective pottery fragments (Andreou \& Kotsakis, 1996). However, the spatial occupation during the EBA is not clear enough as there are no specific architectural characteristics in contrast to the LBA period which represents more organized architectural arrangements in the settlement (Tsoraki 2002).

\subsection{Geological setting of the broader region}

All the locations examined in this study are at the boundary of the Vardar zone and the Circum-Rhodope belt. The city of Thessaloniki, along with the broader region, includes the rock formations of the geological unit Aspri Vrisi-Hortiatis (Figure 2). This unit is positioned parallel to Melissohori-Holomontas unit. Its width is about $4-8 \mathrm{~km}$. The lower part of the provenance consists of Permotriadic metaclastic sediments, volcanoclastic sediments and neritic carbonate sediments. In addition, this part consists of deep sea sediments, such as chert, red clay schist and black graphitic phyllite and quartz schist (Mountrakis 2010). Mafic and ultramafic rocks such as gabbros, diorite and serpentine, represent dismembered bodies of ophiolite outcrops, often found along with deep sea sediments. In the region of Thessaloniki there are also occurrences of metamorphic rocks correlated with acidic magmatic source. These are former granites, diorites, granodiorites, metamorphosed to the greenschist phase and thereby formed into the current gneiss occurrences of Thessaloniki (Mountrakis 2010).

Vasilika and Galatista are located southeast of Toumba, at a distance of $28 \mathrm{~km}$ and $40 \mathrm{~km}$ respectively. Both sites are situated at the upstream part of Anthemountas basin at the boundary between the Vardar zone and the Circum Rhodope belt. Ophiolite outcrops occur in both regions. Ophiolites are parts of the Chalkidiki ophiolite complex with a NW-SE direction. These outcrops include mainly pyroxenites, gabbros, dunites, peridotites and serpentinites. Chromium deposits and magnesite have been recognized in the ultramafic units (Christodoulou \& Michailidis 1990). Chromium deposits of the ophiolitic complex are dominantly massive stratiform ore bodies in dunites (Michailidis 1995). The Chalkidiki ophiolite complex is considered as a detached block of the Vardar oceanic crust, consisting of dismembered bodies which display tectonic contacts with the country rocks. The tectonic contacts between ophiolites and the neighbouring rock formations represent thrust faults. Thus, there are also ophiolite formations that occur in other locations in the broader region, such as in Triadi, Vavdos, Gerakini, Metamorphosis and Toroni. The emplacement of the Vardar oceanic crust on to the continental margin took place in the Upper Jurassic-Lower Cretaceous (Spray et al. 1984).

At the site of Vasilika there is evidence for prehistoric quarrying activity and exploitation of siliceous sedimentary rocks for knapped stone tool manufacture. There is a possible ancient quarry at a distance of $2.5 \mathrm{~km}$ north of the Neolithic settlement of Thermi, in the site of Kiparissi. A link between the settlement of Thermi and the quarry activity in Vasilika during the Neolithic (7,000-3,000 B.C.E.) and Early Bronze Age (3,000-1,800 B.C.E.) has been suggested for the procurement of chert (Grammenos et al. 1992). 


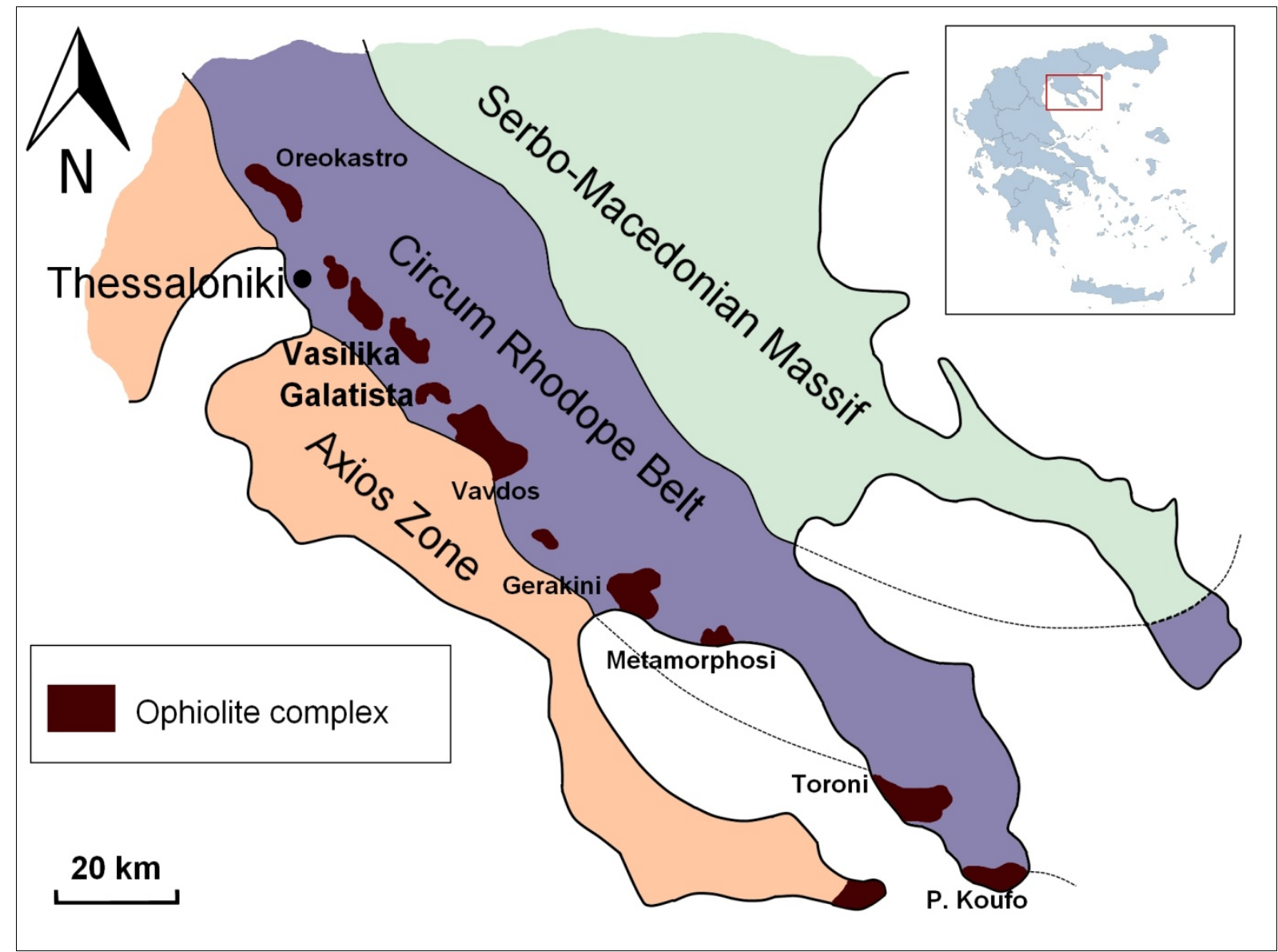

Figure 2.The geological occurrences of the broader region of the study showing the ophiolites in Vardar zone.

\section{Methods}

The samples of chipped stone artefacts come from the Toumba excavation. The geological stone samples derive from the surveyed sites at Vasilika and Galatista. The samples from Vasilika which are only geological samples were collected after a regional fieldwork focusing on a geological-archaeological survey in the frame of a combined project at Anthemountas basin, among the Aristotle University of Thessaloniki, the Ephorate of Antiquities of Thessaloniki City and the Poznań University (Poland). The macroscopic observation included archaeological characterization of the findings and study of their operational sequences. The classification of the samples was mainly based on colour (by using colour characterisations of the Munsell soil colour chart (Munsell 2000), texture and translucency of the materials. Microscopic examination was applied in order to identify the mineralogical composition and the microstructure of the studied samples. Optical microscopy was also applied by using a polarizing microscope at the Department of Mineralogy-PetrologyEconomic Geology at the School of Geology, Aristotle University of Thessaloniki.

\subsection{Geochemical analytical methods}

The determination of the major trace and rare earth elements (REE) of the samples was achieved by inductively coupled plasma mass spectrometry (ICP-MS) at the ACME Analytical Labs (Bureau Veritas), in Vancouver, Canada. The ICP-MS analysis is preferred mainly due to the effective detection abilities. The data of REE of modern sea water and ocean sediments are normalized compared to the prototype sample of PAAS (Post-Archaean Australian Shale Average). For this study the samples were dissolved after using multiple 
acids (multi-acid digestion) with Ultra Trace ICP-MS analysis. The quantity of each pulverized sample was 0.5gr. The samples were heated at a temperature of $150^{\circ} \mathrm{C}$ in a solution form, using $\mathrm{HNO}_{3}$-HF-HCLO 4 . After drying, the residual samples were dissolved in 6 N HCL.

The XRF analysis (X-Ray Fluorescence) was applied in order to identify the major oxides along with the $\mathrm{SiO}_{2}$ percentage in the cherts. The samples were initially pulverized and prepared for the construction of fused beads. The powder of the sample has been mixed with $\mathrm{Li}_{2} \mathrm{~B} 4 \mathrm{O}_{7}$ and then fused at a temperature of $1100^{\circ}-1200^{\circ} \mathrm{C}$. The ratio of sample/Li borate was 1:8.

\section{Results}

\subsection{Macroscopic observation}

Four raw material types were distinguished at the prehistoric Toumba after macroscopic observation: chert, jasper, quartz and chalcedony. These raw material categories are based on an already existing system that has been applied to former archaeological studies in prehistoric sites in northern Greece (Kourtessi-Philippakis 2009).

There have been applied 12 different colour characterizations based on Munsell colour soil chart (Table 1). The four most dominant colour types here are: reddish brown (21\%), brown (16\%), dark reddish brown (16\%) and yellow-red (14\%). The percentage of each raw material from Toumba is as follow: jasper up to 63\%, reddish-brownish cherts up to $13 \%$ other chert varieties $1 \%$, quartz $9 \%$, chalcedony $(1 \%)$ and an $11 \%$ of unrecognized raw materials mainly because these objects were burnt or altered or because they were covered with sediments. There is also a percentage of up to $2 \%$ of other raw materials. Although jasper is considered to be a separate type of raw material especially for the needs of archaeological characterization, we can say that this material form is actually a more reddish type of chert. As the term chert is used as a group name for siliceous sedimentary rocks, other siliceous sediments such as flint, jasper, and chalcedony are also characterized as chert types (Boggs, 2005).

Table 1. The colour characterizations used for the lithic findings from Toumba, based on the Munsell soil colour chart.

\begin{tabular}{lcc}
\hline $\begin{array}{l}\text { Colour } \\
\text { (Munsell Soil Colour Chart) }\end{array}$ & Number of findings & Percentage \% \\
\hline Brown & 149 & 16 \\
Brown-Yellow & 12 & 1 \\
Dark grey & 17 & 2 \\
Dark red; Red & 46 & 5 \\
Dark reddish brown & 148 & 16 \\
Dark reddish grey & 38 & 4 \\
Dusky red & 75 & 8 \\
Light grey & 7 & 1 \\
Pale brown & 16 & 1 \\
Reddish brown & 198 & 21 \\
White & 82 & 9 \\
Yellow-red & 133 & 14 \\
Undefined & 19 & 2 \\
\hline Totals & 940 & $\mathbf{1 0 0 \%}$ \\
\hline
\end{tabular}


Except for the reddish or reddish brown or brownish cherts, there are also some other colour types of siliceous rocks found in the settlement, such as white and black cherts. In some brownish jaspers many darker veins are recognized, which correspond to the existence of iron and manganese oxides.

The raw materials identified respectively from Vasilika and Galatista display similar macroscopic characteristics (Figures 3 and 4). There are brown and reddish brown cherts as well as some darker brownish cherts which indicate the influence of thermal effect.
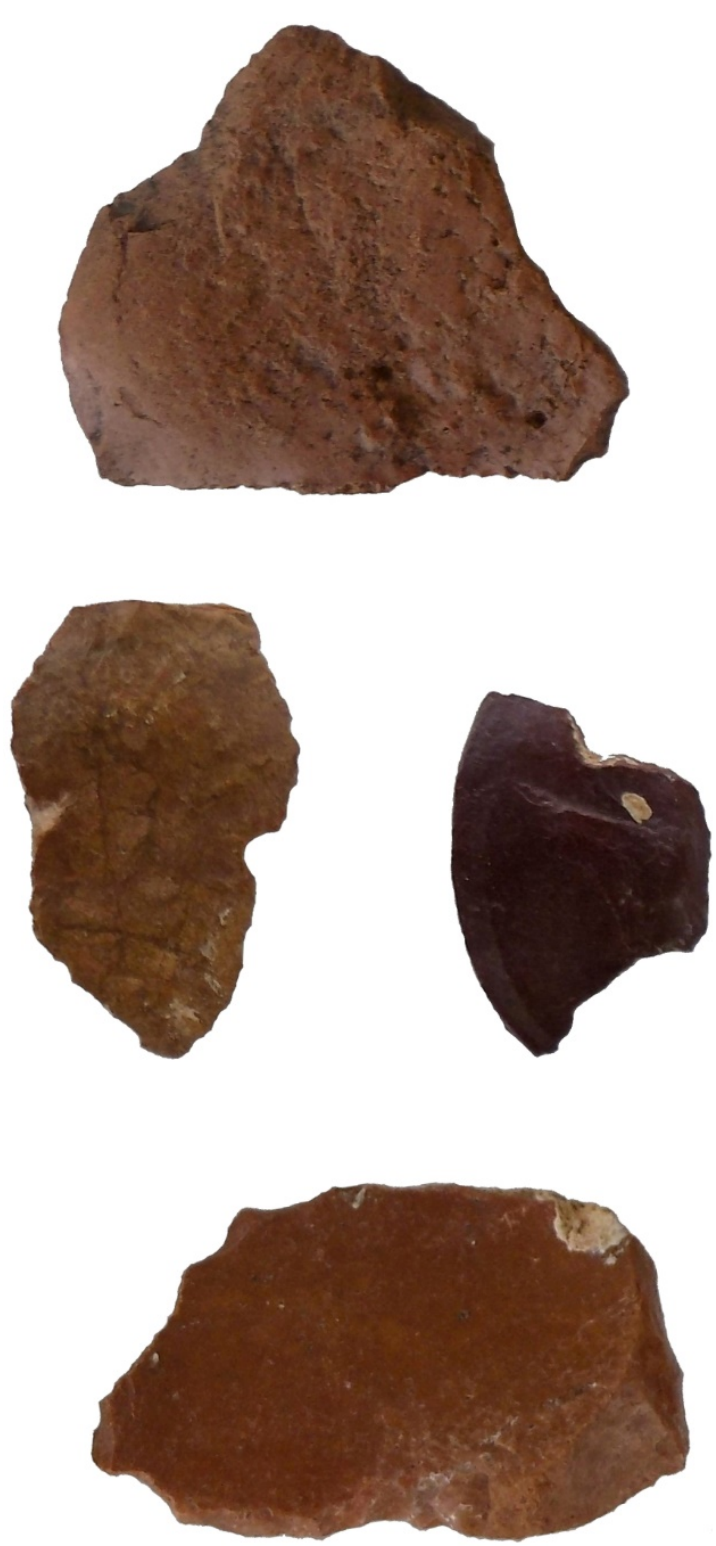

Figure 3. Reddish and brownish chert samples from the site of Vasilika, in northern Greece.

\subsection{Operational sequences}

The operational sequences of chert and jasper processing are complete, including findings such as cores, flakes, blades and some debris. The operational sequence of quartz is less complete with two cores and non-cortex flakes. Raw materials such as black or white cherts have incomplete operational sequences and very few findings as well. 


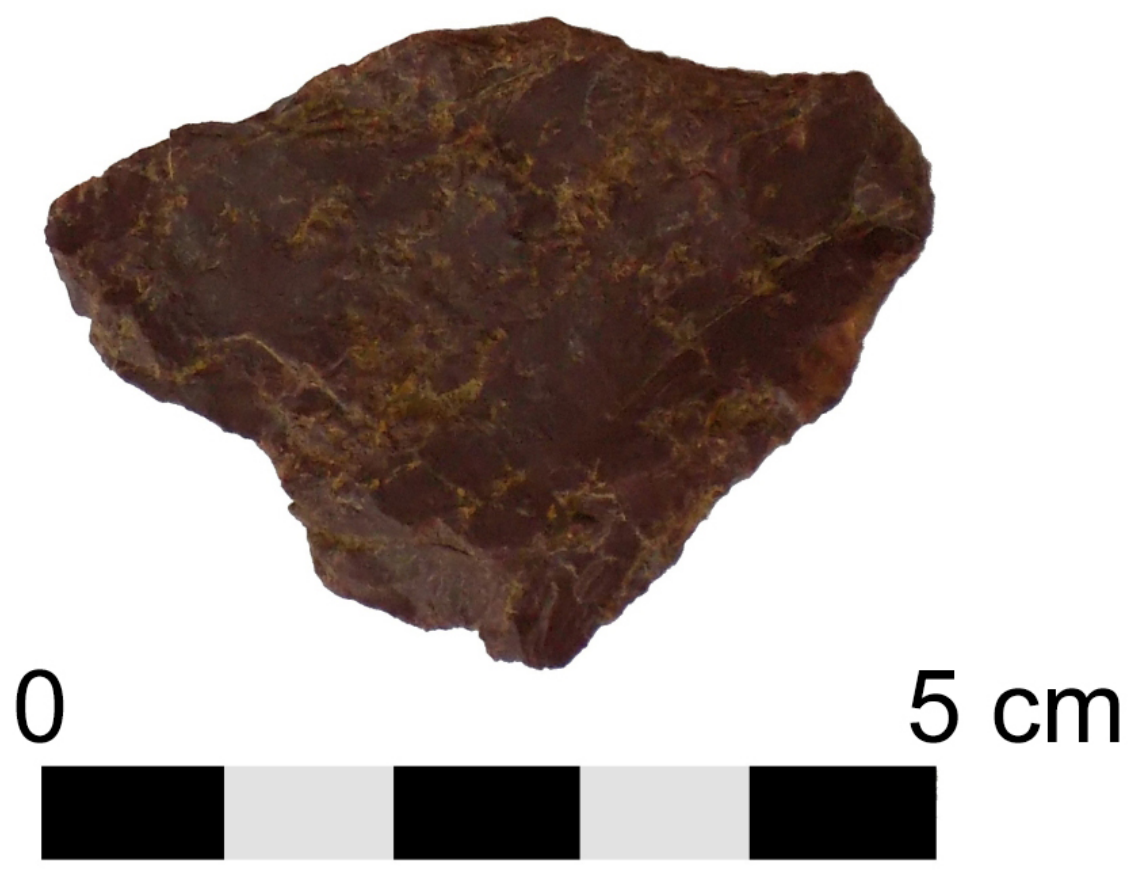

Figure 4. Brown chert from the site of Galatista, in northern Greece.

Flakes and blades were made in order to produce blanks for the making of tools. In a total of 940 lithic objects, $17 \%$ are characterized as tools on the basis of retouch or use-wear modifications (glossed blades, glossed flakes, scrapers, retouched blades, retouched flakes, truncations, spearheads, pegs, drills, notched flakes). The bifacial denticulate flakes are especially characteristic, having an almost square shape and notches with gloss on the one side (Figure 5). The knapping technique mostly preferred is direct percussion with a hard hammer as indicated by the significant thickness of the flakes and the prominent ripples on their ventral face.
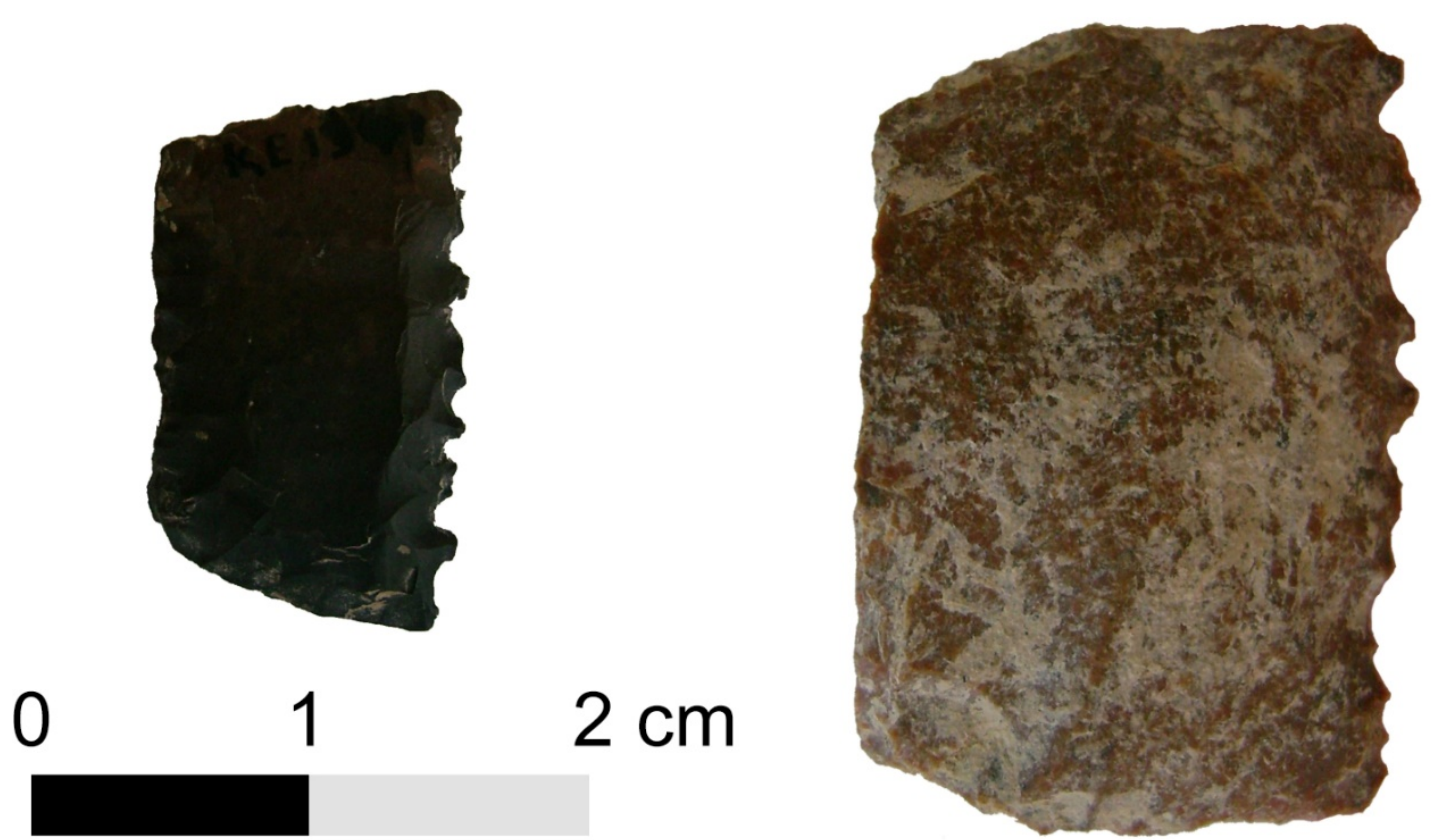

Figure 5. Bifacial denticulate flakes from Toumba with gloss, made of two different colour types of chert. 
In Table 2 and Table 3, the results related to the technological classes of the archaeological material from Toumba and the raw materials that were found at the site are presented. There is a similarity between the operational sequences of reddish-brownish chert types and jasper since they are both complete and include cores, blades, flakes and debris. The cores of the red chert are only three whereas there are 11 cores of jasper. These cores still preserve some detachment surfaces of blades and flakes. As most of these cores were used as pegs afterwards, their surfaces are quite altered and that makes the archaeological analysis considerably complicated. The operational sequence of quartz is quite less complete with no blades and a total amount of 84 findings. The materials that are unidentified include unrecognized raw materials mainly because these objects were burnt or altered or covered with sediments. Moreover, the operational sequence of chalcedony includes only few flakes and debris.

Table 2. The technological classes of archaeological material from Toumba settlement and the respective raw materials that were used.

\begin{tabular}{lccc}
\hline & Red-brown chert & Jasper & Quartz \\
\hline Debris & 40 & 168 & 45 \\
Cores & 3 & 11 & 2 \\
Flakes & 58 & 337 & 37 \\
Blades & 21 & 77 & - \\
Total & 122 & 593 & 84 \\
\hline
\end{tabular}

Table 3. Types of raw materials, found at the prehistoric site of Toumba.

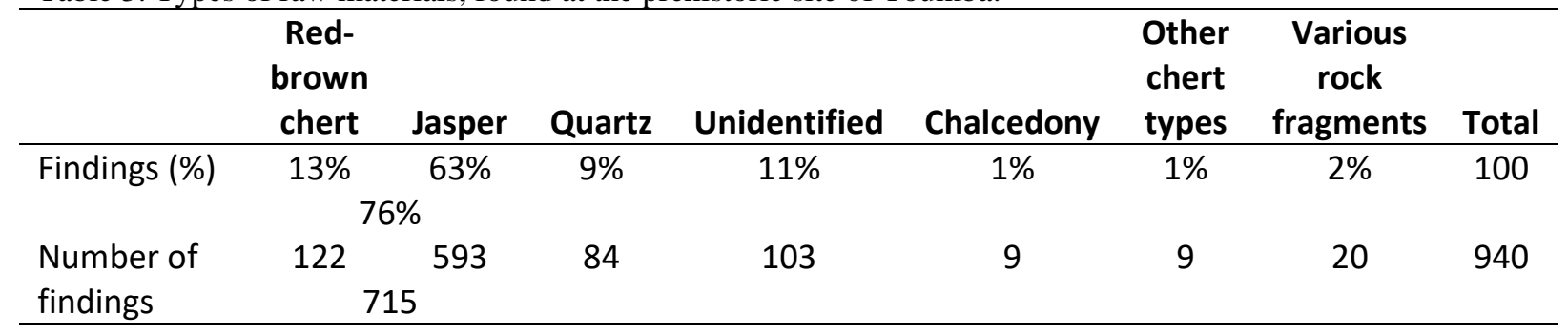

\subsection{Petrographic examination and geochemistry}

The microscopic features of jasper and reddish brown chert are similar. There is a notably high percentage of microcrystalline quartz along with many accessory minerals of iron and manganese oxides (Figure 6). Oxides correspond to hematite, siderite and mainly limonite. Cherts are fine-grained with quartz grain size ranging between 1-10 $\mu \mathrm{m}$. Fibrous chalcedony has also been identified (spheroids) in some of the thin sections of these siliceous sediments (Figure 7).

The chemical analyses indicated that the silica dioxide decreases while the rest of the oxides increase. The percentage of $\mathrm{SiO}_{2}$ is $87-98 \mathrm{wt} \%$ whereas the percentage of $\mathrm{FeO}$ is 4$10 \mathrm{wt} \%$. The $\mathrm{Al}$ oxide is 0.13-3.4 wt\%. The Si-Al diagram (Crerar et al. 1982) shows that these samples are connected with a hydrothermal circulating convection system (Figure 8).

Especially rare earth elements are the most reliable immobile elemental components and provide geochemical models aiming at determining the source because these elements are transferred to the chert from the bedrock and remain stable and unalterable during postdepositional processes such as in diagenesis, alternation and erosion. The concentrations of rare earths were calculated in ppm (Table 4) after applying the ICP-MS analysis. 


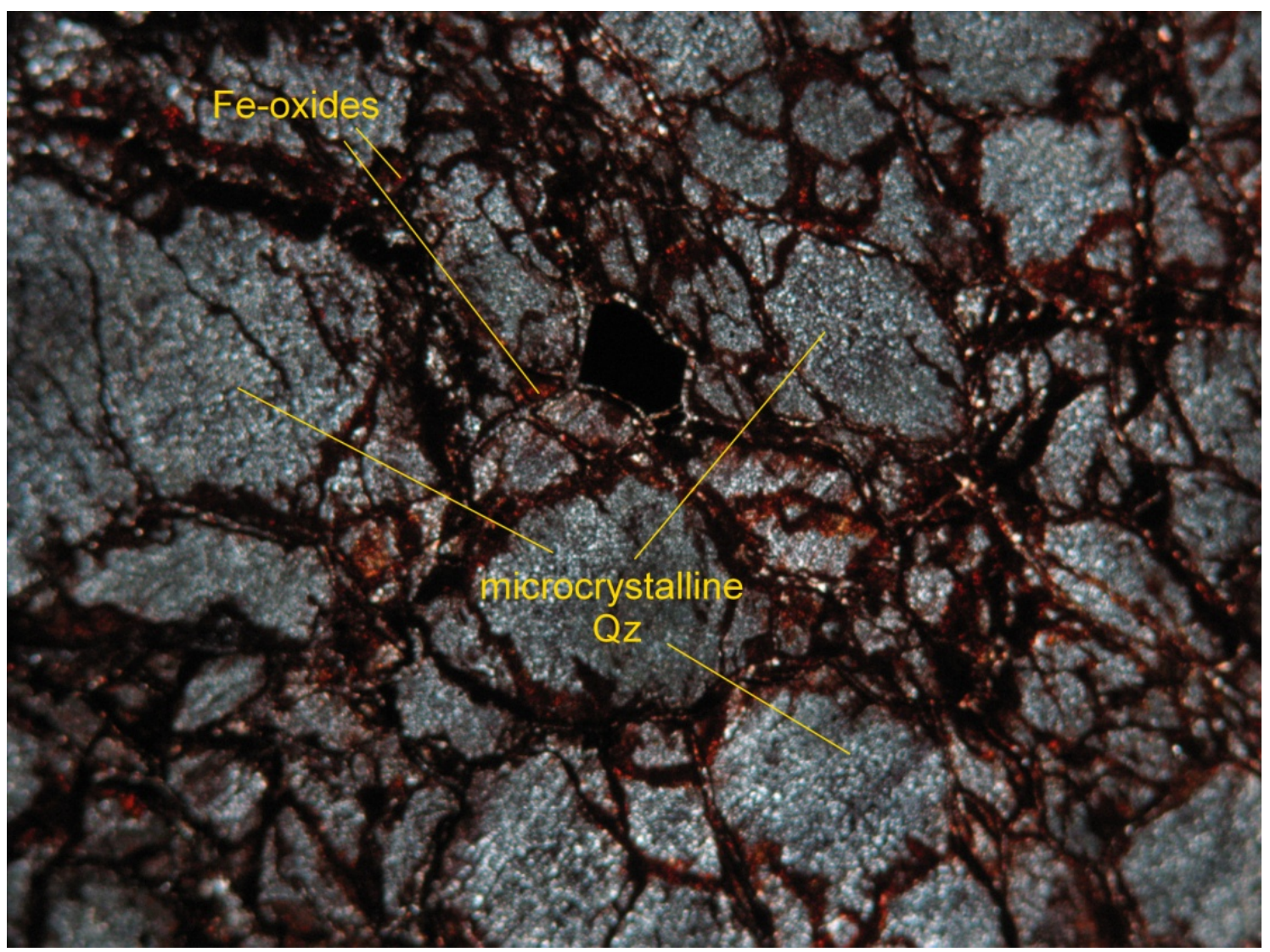

Figure 6. Thin section of a reddish chert sample from Toumba settlement, under crossed polarized light, magnification $\mathrm{x} 5$ (the width of the photo corresponds to $2.8 \mathrm{~mm}$ ).

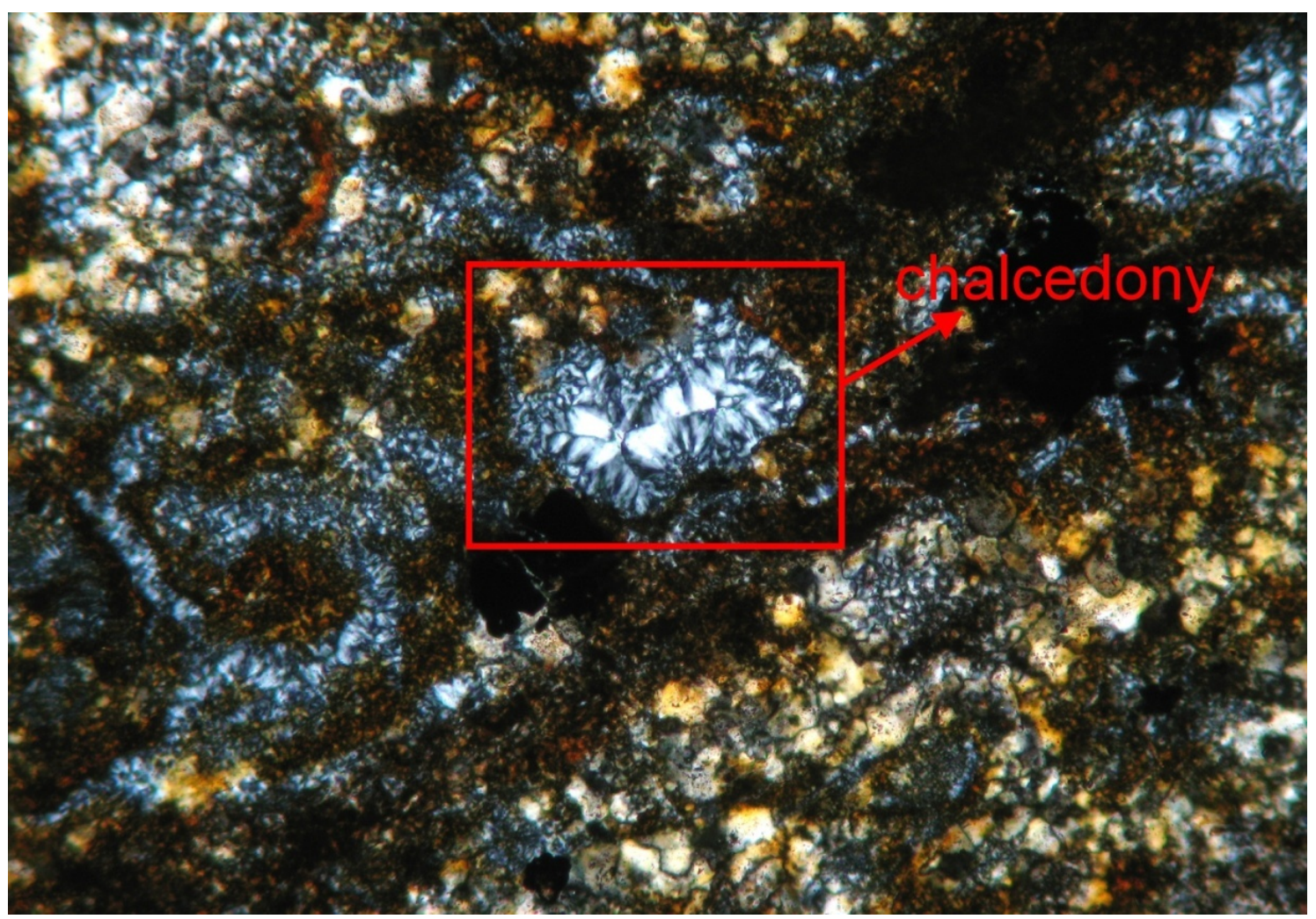

Figure 7. Thin section of a brown chert sample from Vasilika region in northern Greece, under crossed polarized light, magnification $\mathrm{x} 5$ (the width of the photo corresponds to $2.8 \mathrm{~mm}$ ). 


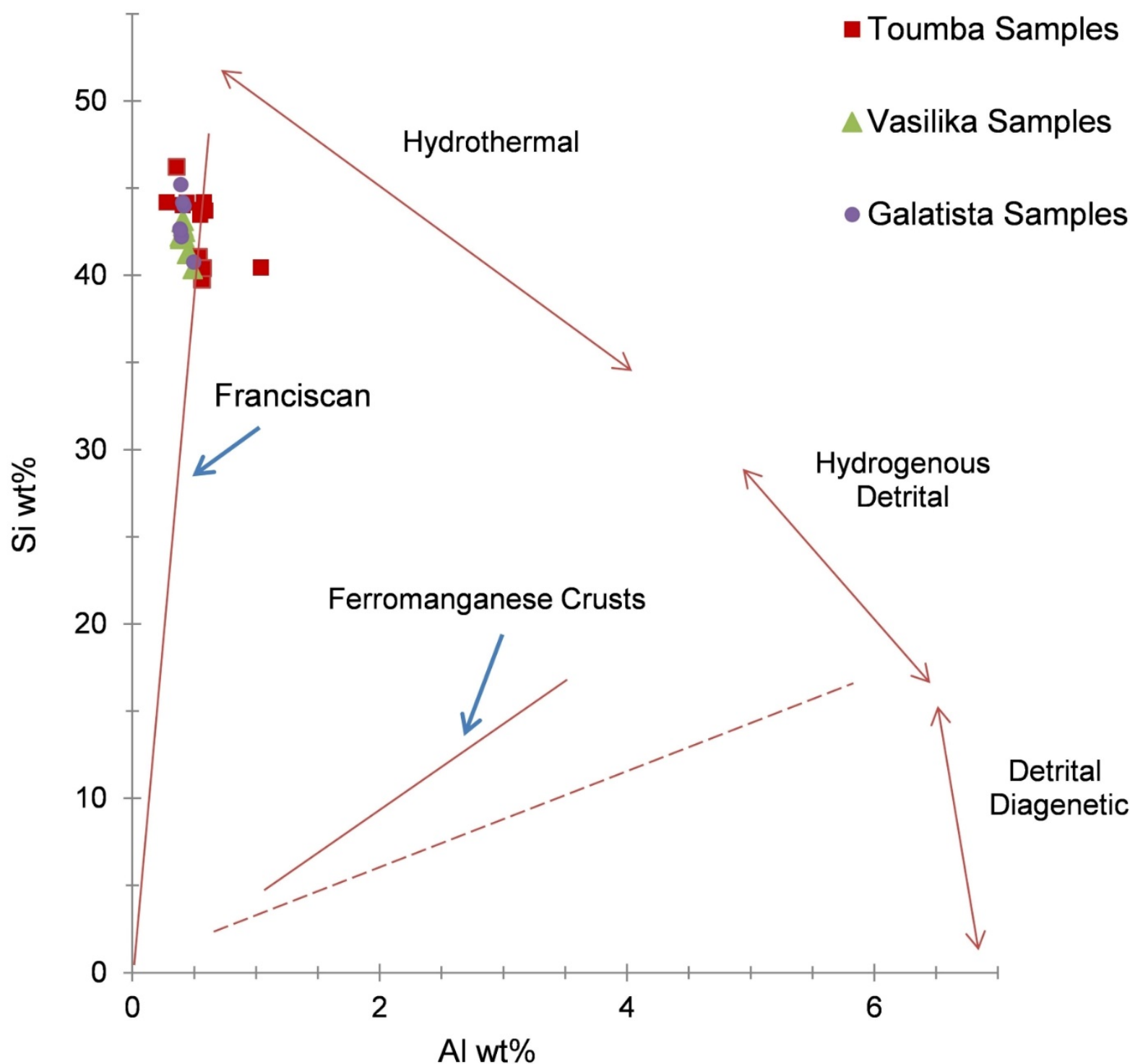

Figure 8. Si-Al diagram which shows that all samples of red and brown siliceous sediments are connected with hydrothermal region.

Cerium anomaly can be considered as evidence for the formation processes and the origin of cherts. Due to the capture of tetravalent Ce by ferromanganese nodules there is a negative Ce anomaly in sea water and positive in Fe-Mn minerals. The chert has a negative anomaly if siliceous sediments have been separated from Fe-Mn minerals. When there is mixing of the two, the Ce-anomaly may be slightly negative up to slightly positive (Junguo et al. 2011). The study of the REE in these cherts from the examined regions included the estimation of Ce anomaly. The ratio of $\mathrm{Ce} / \mathrm{Ce} *$ is about 1-1.8 (Figure 9). This feature could be an indicator of a mixing between ferromanganese nodules and siliceous sediments.

\section{Discussion and conclusions}

The lithic findings from Toumba include mainly objects of siliceous sediments. These materials were classified as cherts and jaspers but in fact they both suggest the same raw material form. The total amount of archaeological findings (tools and other products or fragments as well) that consist of these rock types (reddish cherts and jaspers) is approximately $76 \%$ (715 out of 940 findings). The three most common colour varieties (reddish brown, brown, and dark reddish brown) are quite similar to each other, with very few 
differences. These differences that were taken into account for the classification of the raw materials may be attributed to various factors. The most common factor is that the various raw material types, although derived from the same source, may have minor differences in $\mathrm{Fe}$ content. This information cannot be concluded from a single macroscopic examination. Therefore, microscopic examination and geochemical analyses were also carried out.

Table 4.The minimum, maximum and average values of REE concentrations in the samples investigated geochemically. Abbreviations: bdl - below detection limit.

\begin{tabular}{lccc}
\hline REE & Minimum values (ppm) & Maximum values (ppm) & Average values (ppm) \\
\hline $\mathrm{La}$ & 0.1 & 1.5 & 0.7 \\
$\mathrm{Ce}$ & 0.1 & 2.5 & 1.0 \\
$\mathrm{Pr}$ & $\mathrm{bdl}$ & $\mathrm{bdl}$ & $\mathrm{bdl}$ \\
$\mathrm{Nd}$ & 0.1 & 1.5 & 0.7 \\
$\mathrm{Sm}$ & $<0.1$ & 0.3 & 0.1 \\
$\mathrm{Eu}$ & $\mathrm{bdl}$ & $\mathrm{bdl}$ & $\mathrm{bdl}$ \\
$\mathrm{Gd}$ & $<0.1$ & 0.3 & 0.1 \\
$\mathrm{~Tb}$ & $\mathrm{bdl}$ & $\mathrm{bdl}$ & $\mathrm{bdl}$ \\
$\mathrm{Dy}$ & $<0.1$ & 0.3 & 0.1 \\
$\mathrm{Ho}$ & $\mathrm{bdl}$ & $\mathrm{bdl}$ & $\mathrm{bdl}$ \\
$\mathrm{Er}$ & $<0.1$ & 0.2 & 0.1 \\
$\mathrm{Tm}$ & $\mathrm{bdl}$ & $\mathrm{bdl}$ & $\mathrm{bdl}$ \\
$\mathrm{Yb}$ & $<0.1$ & 0.2 & 0.1 \\
$\mathrm{Lu}$ & $\mathrm{bdl}$ & $\mathrm{bdl}$ & $\mathrm{bdl}$ \\
\hline
\end{tabular}

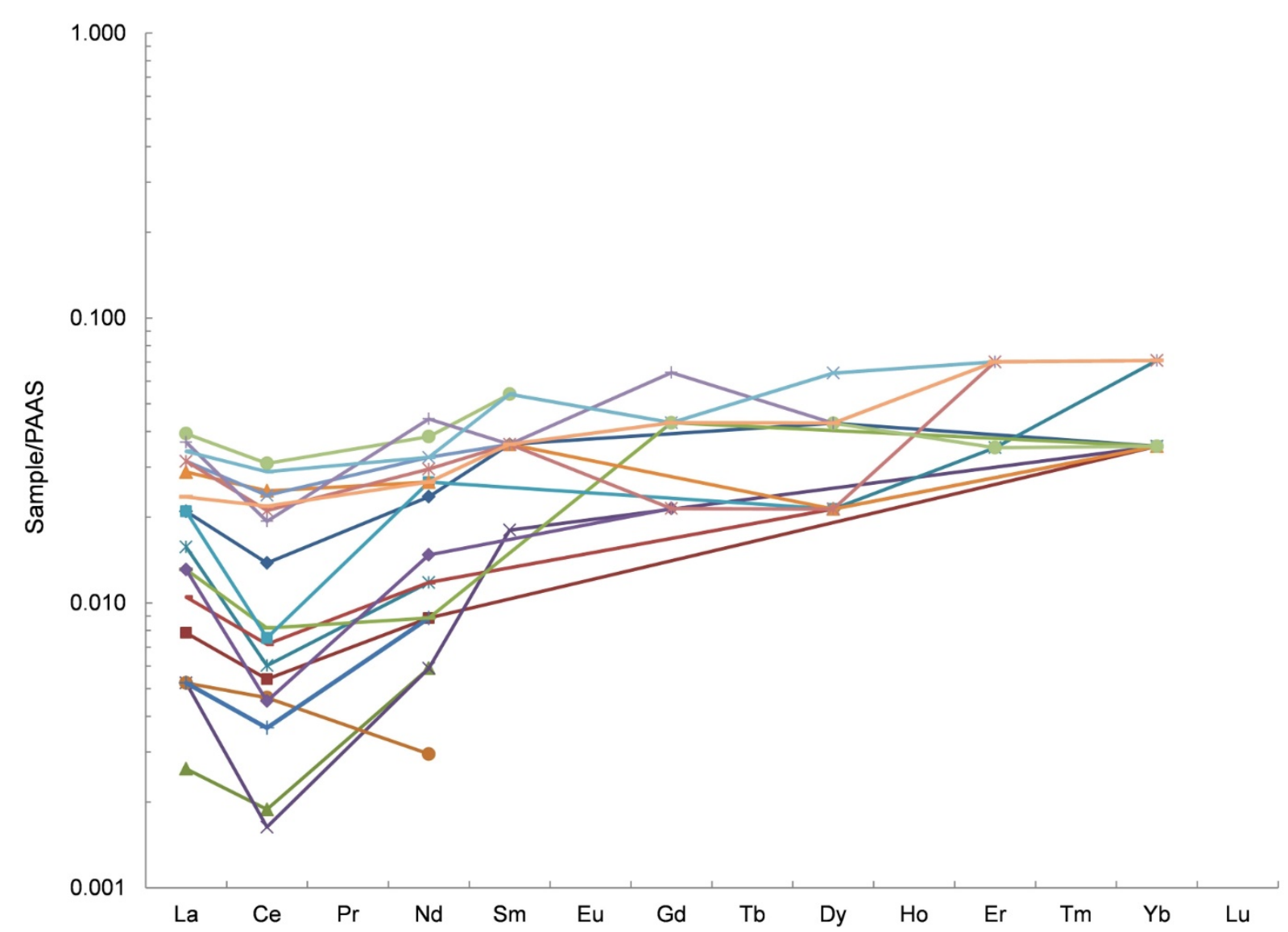

Figure 9. REE diagram that shows the concentrations in the samples that were examined. 
The brownish, reddish and yellowish cherts were found in the three regions of the study, as tool assemblages in Toumba and as geological occurrences in Vasilika and Galatista. By taking into account the existence of ophiolithic formations in Vasilika and Galatista and knowing the connection of these ophiolites with the opening and the formation of oceanic crust, it is concluded that the participation of a hydrothermal system is possible. Silica quantities are extracted from rock formations in greater depths due to the circulation of the hydrothermal solution in water. The Si content is discharged at lower depths and after cooling process.

The darker siliceous sediments (dark red, dusky red) seem to have been under thermal effect. This is also implied by findings with extended dark areas on their lighter original surface. Thermal effect seems to have caused an additional alternation to the texture which turns out to be waxier. Moreover, these darker red findings which seem to have been burnt have the same microscopic features with those objects made of reddish chert types that are not burnt. Even geochemical analyses have not indicated any differences among these objects. In the case of Toumba settlement, the thermal effect can be accidental as the related result is not very limited in many cases. The same assumption can be made for the region of Vasilika as well. In Vasilika there are extended traces of thermal effect on chert outcrops and fragments. Another scenario about this result is that application of heating could indicate a method for exploiting raw materials.

As far as all these red and brown siliceous rocks are concerned, during the archaeological macroscopic identification the terms jasper and chert have been used differently. In this way it is easier to have conclusions which are connected with the archaeological concept and in conjunction with the socio-economic conclusions about the prehistoric settlement, such as the potential differences that might exist to the operational sequences of these raw materials. The examination of the operational sequences through the technological analysis is the first step for the lithic study of a site as through this way they are given conclusions regarding the process stage that the raw materials are imported at the settlement. Red cherts, jasper and quartz present fairly complete operational sequences as several stages of manufacturing are recognized in the settlement. Flakes and blades seem to have been made in order to produce blanks for making tools.

Objects that were macroscopically classified as quartz or white coloured materials consist almost entirely of microcrystalline quartz. In some cases there were identified bigger crystals of quartz. White chert is different than other chert types as it consists not only of quartz but also of $\mathrm{CaCO}_{3}$. The percentage of white cherts from the excavation is less than $1 \%$. The low frequency of white chert among the lithic findings is attributed to the absence of this formation in the broader region. It is very likely that this material originates from a less accessible geological formation or from an even further distance. This can be an evidence of the existence of a broader exchange network in prehistory and more specifically during EBA as the very low percentage of white chert may also indicate a minor importation of products into the settlement. The origin of these products can be identified only by comparing these findings with similar geological occurrences that may exist. Thin bedded recrystallized white cherts exist in the marble blocks in the Vourinos ophiolithic complex in northern Greece (Zimmerman 1972). This may be an example of a potential source for exploitation of white chert, however taking into account that the manufacture of these tools was not made in Toumba's settlement, not only the link of the raw material source should be found but also a potential connection has to be considered with another prehistoric workshop. The long distance of these raw materials can play a major role in the very low presence of them in the Toumba settlement.

Dark grey (or black) and light grey findings do not exceed 3\%. This percentage includes some dark cherts and some other rock types as well, such as minor fragments of apatite and 
schists. The fact that some of them are not siliceous sediments can be identified after the observation of macroscopic characteristics such as texture, gloss, fracture, hardness and clarity. The debate that arises is similar to the case of white cherts from the prehistoric site. There are only few black and grey findings and no such geological occurrences in the broader region. Some of these non-siliceous raw materials are individual fragments of other rock types, such as graphitic schist, which may be accidentally collected by prehistoric man. On the other hand, it is not unlikely these random fragments to indicate an experimentation of prehistoric man with different kinds of materials in an attempt to manufacture objects while trying to compare the suitability of alternative raw materials. Another individual fragment found among others, is a chip of apatite. Moreover, graphitic schist is of a local origin as it is connected with Aspri Vrisi-Hortiatis geological unit.

The sample investigation related to rare earth elements is based on the diverse behaviour of cerium with respect to LREE La, Pr, Nd (Murray 1994). The greatest percentage of REE originates from sea water. Only a minor part of this percentage derives from continental and volcanic residues (Junguo et al. 2011). In general, all rare earth elements in oceanic water have actually continental origin. The supply in this case is made through the river waters ending up to the oceans. In this way it is possible for oceanic sediments to absorb REE. These elements are bound to the surface of sediment grains.

The Ce anomaly can vary to a great extend in different kinds of sediments which derive from various tectonic environments. The dwell time of REE in marine waters has been estimated at $400 \mathrm{yrs}$. This time is clearly shorter than that of the dwell time of main elements. $\mathrm{Ce}$, as well as Eu, has a dwell time of $80 \mathrm{yrs}$ and its chemical properties are not quite similar with respect to the rest rare earths. In continental sediments and in igneous rocks, cerium appears as $\mathrm{Ce}^{3+}$ such as all the rare earths are typically detected in water. However, what happens in marine waters is that Ce can be oxidized and thus results the insoluble tetravalent $\mathrm{Ce}^{4+}$. The tetravalent $\mathrm{Ce}^{4+}$ is being removed very quickly from seawater. The result of this removal is the negative Ce anomaly compared with the rest of the REE (Ding \& Zhong 1996).

The elimination of the dissolved trivalent Ce cation and the rising up of the insoluble $\mathrm{Ce}^{4+}$ takes places selectively in the upper part of the water column. Therefore, acetic sea water develops negative Ce anomaly. On the other hand, the acetic sediments have a less negative up to slightly positive Ce anomaly. On the contrary, anoxic sediments appear to have a negative anomaly as cerium is being released (Chen et al. 2012).

In the case of ferromanganese nodules there is enrichment in $\mathrm{REE}$ and more particularly in Ce. This occurs due to the capture of $\mathrm{Ce}^{4+}$ that exists in water from the ferromanganese nodules (Kato \& Isozaki 2009). According to this case, there can be three stages where in the initial one there is adsorption of the trivalent cerium, together with other rare earths, from $\mathrm{Mn}$ an Fe hydroxides. Subsequently, there is the oxidation of Ce due to surface ablation of Fe and Mn hydroxides: $\left(\mathrm{Ce}^{3+}+\mathrm{MnOOH} \rightarrow \mathrm{CeO}_{2}\right.$ (cerianite) $\left.+\mathrm{Mn}^{2+}+4 \mathrm{H}^{+}\right)$. On the last stage that follows there is the selective adsorption of REE, including the $\mathrm{Ce}^{3+}$ adsorption instead of $\mathrm{Ce}^{4+}$. Ce anomaly is: $\mathrm{Ce} / \mathrm{Ce}^{*}=\mathrm{Ce}_{\mathrm{N}} /\left[\left(\mathrm{La}_{\mathrm{N}}\right)\left(\operatorname{Pr}_{\mathrm{N}}\right)\right]^{1 / 2}$ where $\mathrm{Ce}^{*}$ is the hypothetical concentration of $\mathrm{Ce}^{3+}$ or: $\mathrm{Ce} / \mathrm{Ce}{ }^{*}=2 \mathrm{Ce}_{\mathrm{N}} /\left(\mathrm{La}_{\mathrm{N}}+\mathrm{Pr}_{\mathrm{N}}\right)$ (Kato \& Isozaki 2009). $\mathrm{N}$ stands for the normalized values.

The above results that were given in the present study from the geochemical analyses of the main trace and rare earth elements of the brown and red siliceous rocks from Toumba, Vasilika and Galatista combined with the mineralogical, petrographic and archaeological features reveals that lithic findings of red-brown cherts from Toumba originate from both Vasilika and Galatista. During the Early Bronze Age there was possibly a relation between Toumba inhabitants and these sites for exploiting chert raw material. The results from the geochemical and petrographic research are important to further understanding the operational sequence of chert and jasper tool production. The state in which the raw materials arrived at the site is identified by technological analysis. As the operational sequence is fairly complete, 
it is concluded that the raw materials were being processed in the Toumba settlement. On the contrary, the manufacturing of chalcedony was done outside this site. Both Vasilika and Galatista are situated at significantly small distances (to a maximum distance of $40 \mathrm{~km}$ ). This fact in combination with the complete operational sequences and the choice of the specific raw materials proves that producers were inhabitants of the Toumba settlement and that these people had an easy and direct access to the raw material outcrops of their preference. As indicated previously by Dimitriadis and Skourtopoulou (2001) this kind of local exploitation of raw materials seems to have been a widespread pattern and inhabitants were placing greater focus on both the direct coverage of their needs and maintaining the ownership of specific sites.

Cores and chips were found in the settlement, which indicate on site manufacturing of flakes and blades. Blades and flakes with gloss are the most frequent tools, probably constituting parts of sickles. All the above features suggest that there is no particular preference for certain raw materials. Despite minor macroscopic differences of these materials, mainly in colour, there are no differences in physical and mechanical properties.

All these raw materials with an incomplete operational sequence did not derive from local geological sources, but the origin of quartz is local. There is a possibility that quartz originates from the broader region of Thessaloniki and Chalkidiki in northern Greece and possibly to be associated with granite occurrences. This is concluded by the mineralogical and chemical composition which is similar to quartz occurrences located in the broader region such as in Sohos, Monopigado and Arnea (Papadopoulos 2011). However, the incomplete operational sequence of quartz is probably due to the pure quality of this material for the manufacturing of specific tools, as it does not present the suitable conchoidal fraction in many cases. As for the non-local materials in combination with the existence of raw materials from regions very close to the settlement, that indicates the fact that the inhabitants were making choices about the raw materials they wanted to utilize.

\section{References}

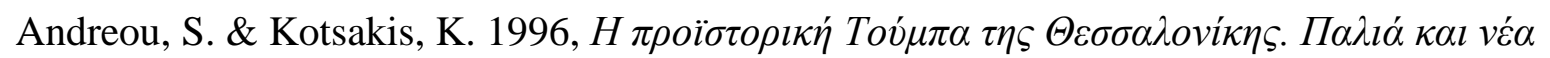

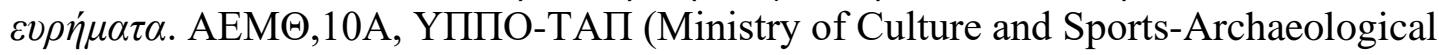
Receipts Fund), Thessaloniki, 369 p. (in Greek) ("The prehistoric Toumba of Thessaloniki. Old and new evidence")

Boggs, S.J. 2005, Petrology of Sedimentary Rocks (2nd ed.). Cambridge University Press, Cambridge, $607 \mathrm{p}$.

Chen, L., Tien-Shun Lin, A., Da, X., Yi, H., Tsai, L.L.Y. \& Xu, G. 2012, Sea-level changes recorded by cerium anomalies in the Late Jurassic (Tithonian) black rock series of Qiangtang basin, North-Central Tibet. Oil Shale, 29(1): 18. doi:10.3176/oil.2012.1.03

Christodoulou, C. \& Michailidis, K. 1990, Petrology of the plutonic suites from the Chalkidiki ophiolites, northern Greece. Implications for parental magma characteristics and tectonic provenance. Ofioliti, 15(1): 17-44.

Crerar, D.A., Namson, J., Chyi, M.S., Williams, L. \& Feigenson, M.D. 1982, Manganiferous cherts of the Franciscan assemblage; I, General geology, ancient and modern analogues, and implications for hydrothermal convection at oceanic spreading centers. Economic Geology, 77(3): 519-540. doi:10.2113/gsecongeo.77.3.519 
Dimitriadis, D. \& Skourtopoulou, K. 2001, Characterization of lithic materials by petrographic and SEM techniques: Towards suggestions on chipped stone tool

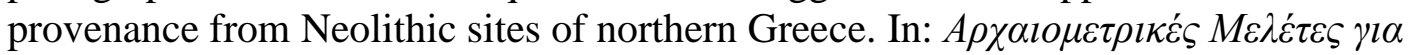

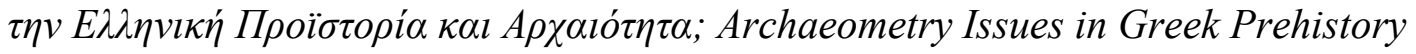
and Antiquity (Bassiakos, Y., Aloupi, E. \& Facorellis, Y., Eds.), Hellenic Society for Archaeometry and Society of Messenian Archaeological studies, Athens: p. 779-790.

Ding, L. \& Zhong, D. 1996, Characteristics of rare earth elements and cerium anomalies in cherts from the Paleo-Tethys in Changning-Menglian belt in western Yunnan, China. Science in China D, 39(1): 35-45.

URL: http://earth.scichina.com:8080/sciDe/EN/10.1360/yd1996-39-1-35

Grammenos, D.V., Pappa, M., Ourem-Kotsos, N., Skourtopoulou, K., Giannouli, E.,

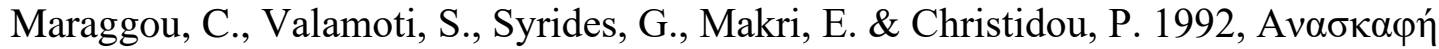

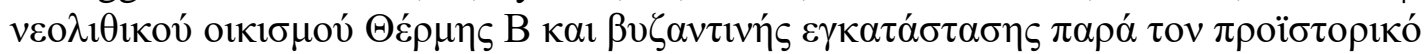

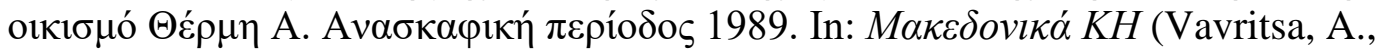
Vakalopoulou, A., Pantermali, A., Samsari, D., Touloumakou, I. \& Tsigarida, E., Eds.), Society of Macedonian Studies, Thessaloniki: p. 381-501. (in Greek) ("Excavation of the Neolithic settlement Thermi B and Byzantine installation despite the prehistoric settlement of Thermi A. Excavation period 1989")

Junguo, H., Yongzhang, Z. \& Hongzhong, L. 2011, Study on Geochemical Characteristics and Depositional Environment of Pengcuolin Chert, Southern Tibet. Journal of Geography and Geology, 3(1): 178-188. doi:10.5539/jgg.v3n1p178

Kato, Y. \& Isozaki, Y. 2009, Comment on "Evaluation of palaeo-oxygenation of the ocean bottom cross the Permian-Triassic boundary” by Kakuwa (2008): Was the Late Permian deep-superocean really oxic? Global and Planetary Change, 69(1-2): 79-81. doi:10.1016/j.gloplacha.2009.01.003

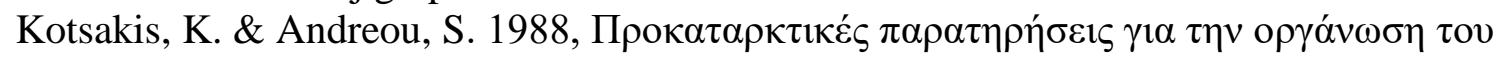

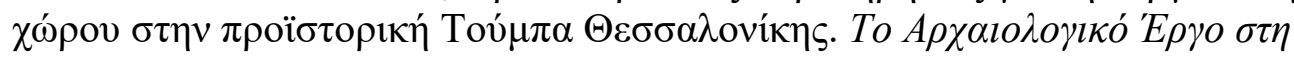

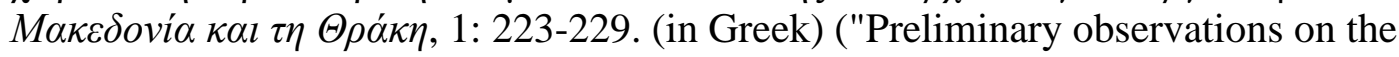
organization of space in prehistoric Toumba Thessaloniki")

Kourtessi-Philippakis, G. 2009, Lithics in Neolithic Northern Greece: territorial perspectives from an off-obsidian area. Documenta Praehistorica, 36: 305-311. doi:10.4312/dp.36.19

Michailidis, K.M. 1995, Compositional variation of zoned chromian spinels in serpentinites from the Killkis area, Northern Greece. Chemie Der Erde-Geochemistry, 55(2): 81-96.

Mitropoulos, P., Sideris, C. \& Grimanis, A.P. 1990, Provenance studies of ancient flint tools from the Franchthi Cave in the Peloponnese, Greece: A geochemical approach. In: Archaeometry '90: Proceedings of the 27th Symposium on Archaeometry held iv Heidelberg, April 2-6, 1990 (Wagner, G.A. \& Pernicka, E., Eds.), Birkhauser Verlag, Basel: p. 485-494.

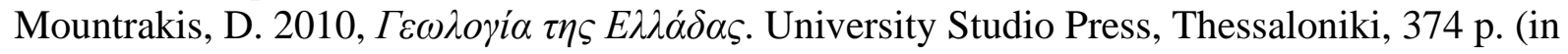
Greek) ("Geology of Greece")

Munsell Color 2000, Munsell Color Soil Chart. Munsell Color, Baltimore Maryland, 10 p.

Murray, R.W. 1994, Chemical criteria to identify the depositional environment of chert: general principles and applications. Sedimentary Geology, 90(3-4): 213-232. doi:10.1016/0037-0738(94)90039-6 


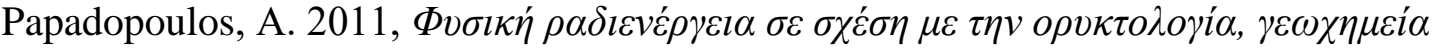

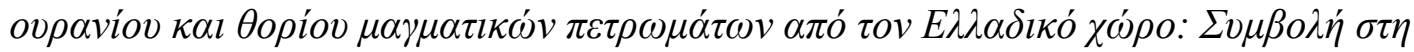

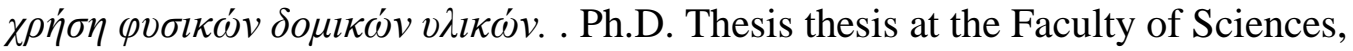
School of Geology, Aristotle University of Thessaloniki, Thessaloniki, 297 p. (in Greek) ("Natural radioactivity in relation to mineralogy, geochemistry of uranium and thorium of magmatic rocks from Greece: contribution to the use of natural building materials") doi:10.12681/eadd/24651

Spray, J.G., Bébien, J., Rex, D.C. \& Roddick, J.C. 1984, Age constraints on the igneous and metamorphic evolution of the Hellenic-Dinaric ophiolites. Geological Society, London, Special Publications, 17(1): 619-627. doi:10.1144/gsl.sp.1984.017.01.48

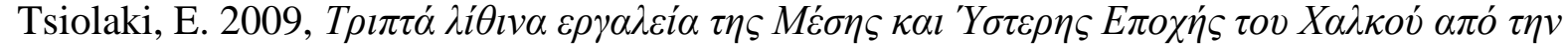
Tov́ $\mu \pi \alpha \Theta \varepsilon \sigma \sigma \alpha \lambda$ ovík $\eta$. Master Thesis thesis at the School of Philosophy, Department of History and Archaeology, Aristotle University of Thessaloniki, Thessaloniki, 159 p. (in Greek) ("Ground stone tools of Middle and Late Bronze Age from Toumba, Thessaloniki") URL: http://ikee.lib.auth.gr/record/114463

Tsoraki, C. 2002, Lithic practice in perspective: the chipped stone artefacts from Toumba Thessaloniki, Greece. Unpublished Master Dissertation thesis at University of Sheffield, Department of Archaeology and Prehistory, Sheffield, xx p.

Tucker, M.E. 2001, Sedimentary Petrology. An Introduction to the Origin of Sedimentary Rocks (3rd ed.). Blackwell Publishing, Oxford, 272 p.

Zimmerman, J. 1972, Emplacement of the Vourinos Ophiolitic Complex, Northern Greece. Geological Society of America Memoirs, 132: 225-240. doi:10.1130/MEM132-p225 